\title{
Seroprevalence and risk factors for cattle anaplasmosis, babesiosis, and trypanosomiasis in a Brazilian semiarid region
}

\author{
Soroprevalência e fatores de risco para anaplasmose, babesiose e \\ tripanosomíase bovina em uma região semiárida do Brasil \\ Valéria Medeiros de Mendonça Costaํㅜ Múcio Flávio Barbosa Ribeiro²; Amélia Lizziane Leite Duarte; \\ Julia Marry Mangueira ${ }^{1}$; André Flávio Almeida Pessoa ${ }^{1}$; Sergio Santos Azevedo'; \\ Antonio Thadeu Medeiros de Barros ${ }^{3}$; Franklin Riet-Correa ${ }^{1}$; Marcelo Bahia Labruna*
}

${ }^{1}$ Unidade Acadêmica de Medicina Veterinária, Centro de Saúde e Tecnologia Rural,

Universidade Federal de Campina Grande - UFCG, Patos, PB, Brasil

${ }^{2}$ Departamento de Parasitologia, Instituto de Ciências Biológicas, Universidade Federal de Minas Gerais - UFMG, Belo Horizonte, MG, Brasil

${ }^{3}$ Empresa Brasileira de Pesquisa Agropecuária, Centro de Pesquisa Agropecuária do Pantanal, Corumbá, MS, Brasil

${ }^{4}$ Departamento de Medicina Veterinária Preventiva e Saúde Animal, Faculdade de Medicina Veterinária e Zootecnia, Universidade de São Paulo - USP, Brasil

Received June 12, 2012

Accepted February 18, 2013

\begin{abstract}
The seroprevalence of Anaplasma marginale, Babesia bigemina, Babesia bovis and Trypanosoma vivax and the risk factors for these infections were investigated in 509 cows on 37 farms in the semiarid region of Paraíba, northeastern Brazil. Cow serum samples were tested by means of immunofluorescence assay (IFA) against each specific antigen. The mean seroprevalence values per farm were $15.0 \%$ (range: $0-75 \%$ ) for $A$. marginale, $9.5 \%$ (range: $0-40 \%$ ) for $B$. bigemina and $26.9 \%$ (range: $0-73.7 \%$ ) for B. bovis. All cows tested negative for T. vivax. Higher prevalence for $A$. marginale was significantly associated with less frequent acaricide spraying per year and with higher use of injectable antihelminthics. Presence of cows positive for B. bigemina was significantly associated with acaricide use and with presence of horse flies on the farm. Both occurrence and higher prevalence of $B$. bovis were significantly associated with recent observations of ticks on cattle. Overall, the present results indicate that the region investigated is an enzootically unstable area for A. marginale, B. bigemina and B. bovis, since most animals were seronegative to at least one agent.
\end{abstract}

Keywords: Anaplasma marginale, Babesia bigemina, Babesia bovis, cattle, risk factors, Brazil.

\section{Resumo}

A soroprevalência de Anaplasma marginale, Babesia bigemina, Babesia bovis e Trypanosoma vivax, assim como os fatores de risco para estas infecçôes, foram investigadas em 37 fazendas (total de 509 vacas) da regiáo semiárida da Paraíba, nordeste do Brasil. A presença de anticorpos nos soros dos animais foi detectada pela técnica de imunofluorescência indireta, utilizando antígenos específicos. Os valores médios de soroprevalência por fazenda foram 15,0\% (0-75\%) para A. marginale, 9,5\% (0-40\%) para B. bigemina, e 26,9\% (0-73,7\%) para B. bovis. Todas as vacas foram soronegativas para T. vivax. As maiores prevalências de $A$. marginale foram significativamente associadas com menor uso de carrapaticidas por ano e com uso mais frequente de antihelmínticos injetáveis. A soroprevalência de $B$. bigemina foi significativamente associada com o uso de carrapaticidas, e com a presença de mutucas na fazenda. Tanto a ocorrência como a maior soroprevalência para $B$. bovis nas fazendas foram significativamente associadas com a presença recente de carrapatos nos bovinos. No geral, os resultados indicam que as fazendas amostradas estão situadas em área de instabilidade enzoótica para $A$. marginale, B. bigemina, e $B$. bovis, uma vez que a maioria dos animais foi soronegativa para pelo menos um dos agentes.

Palavras-chave: Anaplasma marginale, Babesia bigemina, Babesia bovis, bovino, fatores de risco, Brasil.

\footnotetext{
*Corresponding author: Marcelo Bahia Labruna

Departamento de Medicina Veterinária Preventiva e Saúde Animal, Faculdade

de Medicina Veterinária e Zootecnia, Universidade de São Paulo - USP,

Av. Professor Orlando Marques de Paiva, 87, Cidade Universitária,

CEP 05508-270, São Paulo, SP, Brasil

e-mail: labruna@usp.br
} 


\section{Introduction}

With over 200 million cattle, Brazil has the largest commercial herd in the world, and most of these animals are exposed to the cattle tick, Rhipicephalus (Boophilus) microplus. Most of the time, $R$. (B.) microplus is the sole tick species infesting cattle in Brazil (ARAGÃO, 1936; CAMPOS PEREIRA et al., 2008). This tick species is a primary vector of the bacterium Anaplasma marginale and the protozoa Babesia bigemina and Babesia bovis, which may contribute towards the generally high prevalence of such tick-borne agents throughout the country. However, occurrences of diseases caused by these agents are generally dependent on the climatic conditions of each region. In most of the country, cattle babesiosis and anaplasmosis occur endemically because environmental conditions provide moderate to high $R$. (B.) microplus burdens infesting pastured cattle throughout the year. In this case, cattle generally become infected by $A$. marginale, $B$. bigemina and $B$. bovis during the first weeks or months after birth, and then remain infected (seropositive) without suffering severe disease for the rest of their lives (RIBEIRO; REIS, 1981; MADRUGA et al., 1984, 1985; PATARROYO et al., 1987; SANTOS et al., 2001). On the other hand, environmental conditions in some areas are not suitable for $R$. (B.) microplus throughout the year, such as in southern Brazil (and Uruguay), where mean temperatures below $15^{\circ} \mathrm{C}$ inhibit tick development during the autumn-winter months. Consequently, many animals do not come into contact with infected ticks during their first months, and when they first become infected later on, severe disease with high lethality is a common feature (NARI; SOLARI, 1991; MARTINS et al., 1994; GUGLIELMONE, 1995; MARANA et al., 2009).

The African agent for surra, Trypanosoma vivax, which was first reported in South America in the early $20^{\text {th }}$ century, is considered to be mechanically transmitted by biting flies, such as tabanids and Stomoxys calcitrans (HOARE, 1972). These flies have also been incriminated as mechanical vectors for $A$. marginale (HAWKINS et al., 1982; KESSLER, 2001). In Brazil, T. vivax has been sporadically reported infecting ruminants, as recently reported in three outbreaks affecting cattle in the semiarid region of the State of Paraíba (BATISTA et al., 2007, 2008).

The state of Paraíba, located in the northeastern region of Brazil, is characterized by warm weather throughout the year. The state is geographically subdivided into the following four major regions, based mostly on vegetation type and rainfall: (i) Zona da Mata (Atlantic forest), (ii) Agreste, (iii) Cariri, and (iv) Sertão (Figure 1). The Zona da Mata and Agreste have relatively higher rainfall regimes (CABRERA; WILLINK, 1973). Both Cariri and Sertâo (the semiarid region) are typically within the Caatinga biome, which encompasses an area of $900,000 \mathrm{~km}^{2}(11 \%$ of Brazilian territory) and is the only major biome that occurs exclusively in Brazil. Caatinga is xeric shrubland and thorn forest, which consists primarily of small, thorny trees that shed their leaves seasonally. Cacti, thick-stemmed plants, thorny brush and arid-adapted grasses make up the ground layer; however, during the dry periods there is no ground foliage or undergrowth (ANDRADE-LIMA, 1981). The weather is characterized by a hot and semiarid climate, with temperatures averaging $27{ }^{\circ} \mathrm{C}$, and the mean annual rainfall is typically $\approx 500 \mathrm{~mm}$. There are typically two seasons: a rainy season from February to May, and a long drought period from June to January. However, occurrences of droughts sometimes lasting for longer than one year is also a characteristic of the region (BATISTA et al., 2007). Indeed, this usually long drought period has important implications that are yet to be evaluated under natural conditions, for the vectors of $A$. marginale and Babesia spp. in relation to cattle raised in the Caatinga biome.

During the last few decades, dairy cattle have become significantly important within animal husbandry in Paraíba. Except for the Zona da Mata region (where sugarcane crops prevail), small cattle-raising farms are widespread in the Agreste, Cariri and Sertão regions. Whereas cultivated grasses (mostly Brachiaria spp.) are the basis for Agreste livestock, cattle are usually reared extensively on native Caatinga in most of the Cariri and Sertão farms. Until very recently, cattle babesiosis or anaplasmosis had remained unreported in the Caatinga biome of the state of Paraíba. A recent study by our group described 24 outbreaks of cattle anaplasmosis and/or babesiosis on cattle farms in the Sertão region of that state (COSTA et al., 2011). These outbreaks mostly affected cows, with a 36\% mean lethality rate (range: $0-100 \%$ ), thus indicating that many of the affected cows were not immune, i.e. they had not previously been infected by Anaplasma or Babesia agents. Here, for the first time, we investigated the seroprevalence of cattle for A. marginale, B. bigemina, B. bovis and T. vivax on farms in the semiarid region of Paraíba, as well as the risk factors for these agents.

\section{Materials and Methods}

From July 2009 to July 2010, blood samples were collected from cattle on 37 small farms in the state of Paraíba, of which 25 were in the Sertão, 9 in the Cariri and 3 in the Agreste region (Figure 1). A total of 509 blood samples were obtained. On each farm, 5 to 30 cows were sampled. Only small farms with herd sizes ranging from 8 to 180 cattle were investigated. During farm visits, a standard questionnaire was applied to the farm owner or manager in order to obtain information for studying the risk factors. The independent variables studied are shown in Table 1.

Each cow serum sample was tested by means of immunofluorescence assay (IFA) against antigens of $A$. marginale strain UFMG1, $B$. bigemina strain BbigMG, $B$. bovis strain BbovMG and T. vivax strain IgarapeMG, as previously described (BASTOS et al., 2010; CUGLOVICI et al., 2010). For the first three agents, the antigens consisted of parasitized erythrocytes obtained from splenectomized calves that had been experimentally inoculated (IICA, 1987). The antigens for T. vivax consisted of fixed trypomastigotes, obtained from an experimentally-infected splenectomized goat (CUGLOVICI et al., 2010). Serum samples were considered positive if they displayed a specific reaction to one of the four antigens, at the 1:80 serum dilution. In each reaction, we used appropriate negative and positive control sera from experimentally or naturally-infected cattle with each of the agents (COSTA-JÚNIOR et al., 2006; BASTOS et al., 2010; CUGLOVICI et al., 2010).

The proportions of the cows that were serologically positive for A. marginale, B. bigemina or B. bovis were calculated separately for 


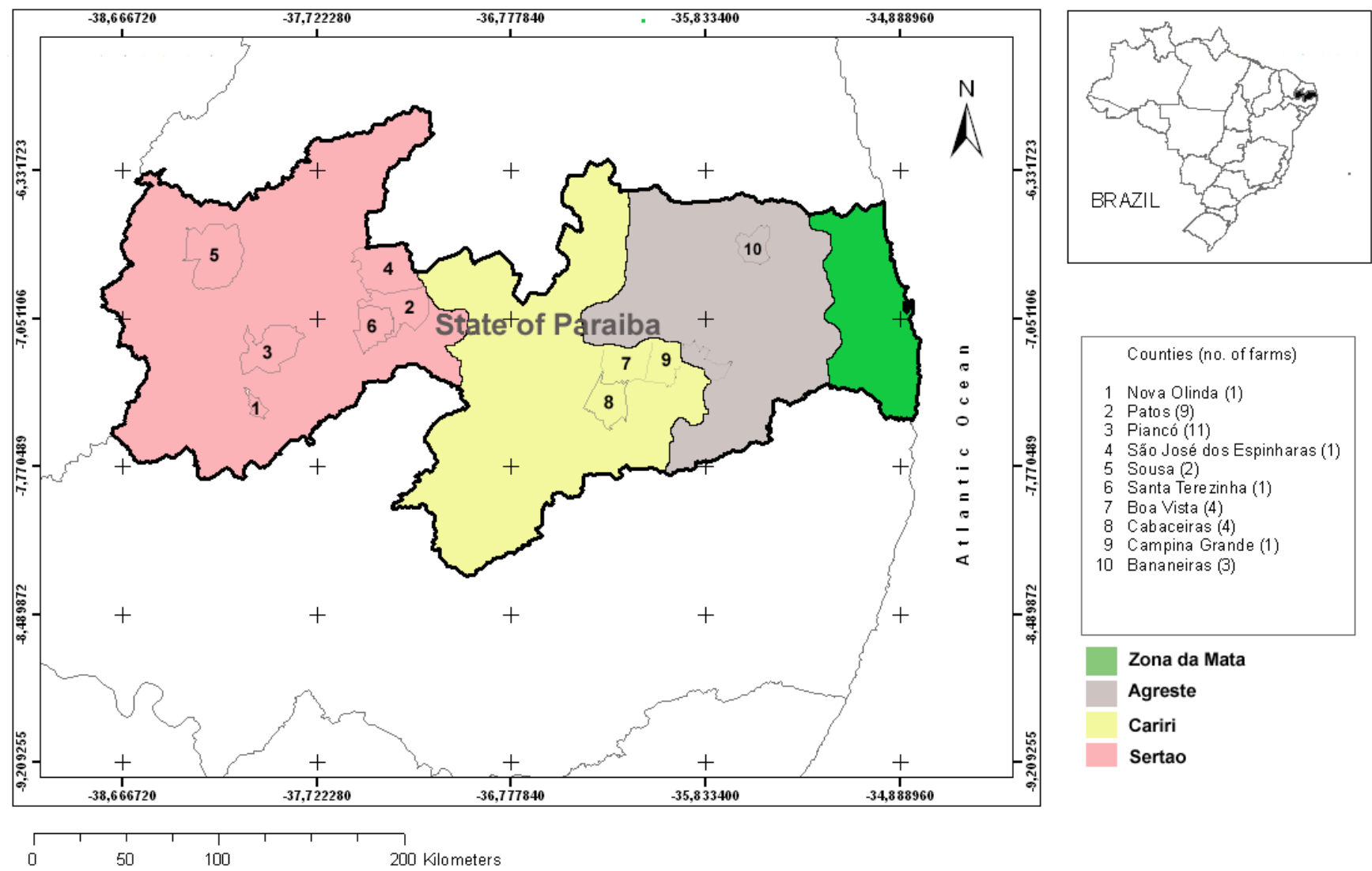

Figure 1. Numbers of farms per county (municipality) according to the geographic regions of the state of Paraíba, northeastern Brazil.

each farm. For data analysis, logistic regression was performed to construct multivariate models that could explain the dependent variables (cows serologically positive for $A$. marginale, $B$. bigemina or $B$. bovis) as a function of the 24 independent variables, dichotomously $($ absence $=0$; presence $=1)($ Table 1$)$. The serological results from each farm were analyzed at two separate dichotomous levels: firstly, with the presence or absence of serologically positive cows (no positive cow $=0$; at least one positive cow on the farm = 1); and secondly, as the proportion of positive cows on the farm (less than $25 \%$ of cows positive $=0$; more than $25 \%$ of cows positive $=1$ ). The independent variables were subjected to univariate analysis and those with a statistical association (here considered to be $P<0.20$, using the chi-square test, for this first analysis) were tested in the multivariate model by means of the stepwise forward method. The variables were included in the multivariate model if they displayed statistical significance of $P<0.05$, considering also the significance level of the final model. All analyses were performed using SPSS for Windows (SPSS, 1999).

\section{Results}

Among the 509 cows sampled, 211 (41.5\%) were seropositive for at least one agent. Simple infection was observed in 170 cows (33.4\%), of which 53 were positive solely for $A$. marginale, 33 solely for $B$. bigemina and 84 solely for $B$. bovis; dual infection was observed in 34 cows (6.7\%), of which 24 for both $A$. marginale and $B$. bovis, and 10 for both $B$. bigemina and $B$. bovis; triple infection, namely, seropositivity for $A$. marginale, $B$. bigemina and $B$. bovis, was detected in only 7 cows $(1.4 \%)$. All the cows were seronegative for T. vivax. Overall seroprevalence values according to geographic regions are shown in Table 2 . The number of cows sampled per farm ranged from 5 to 30 (mean: $13.8 \pm 6.2$ ). The mean seroprevalence values per farm were $15.0 \pm 18.1 \%$ (range: $0-75 \%$ ) for $A$. marginale, $9.5 \pm 12.5 \%$ (range: $0-40 \%$ ) for $B$. bigemina and $26.9 \pm 24.1 \%$ (range: $0-73.7 \%$ ) for $B$. bovis. Among the 37 farms sampled, all the cows were negative for $A$. marginale, $B$. bigemina and $B$. bovis, respectively, on 14 (37.8\%), 18 (48.6\%) and 7 (18.9\%) of the farms. Seropositivity prevalences above $25 \%$ for $A$. marginale, B. bigemina and B. bovis, respectively, were observed on $10(27.0 \%), 4(10.8 \%)$ and $17(45.9 \%)$ of the farms.

By means of univariate analysis, the presence of at least one cow serologically positive for $A$. marginale was statistically coupled $(P<0.20)$ with variable nos. 3, 9, 18, 20 and 23 (Table 1). However, when these independent variables were subjected to multivariate analysis, none was significant. Univariate analysis showed that situations with more than $25 \%$ of the cows serologically positive for $A$. marginale were statistically coupled $(P<0.20)$ with variable nos. 2, 3, 4, 12, 13, 19 and 20. When these independent variables were subjected to multivariate analysis, only use of less than four acaricide sprayings per year (no. 13), and more than two 
Table 1. Dichotomous categories of each independent variable used in the statistical analysis of seropositivity of cows for Anaplasma marginale, Babesia bigemina and Babesia bovis in the state of Paraíba, Brazil.

\begin{tabular}{|c|c|c|c|}
\hline No. & Independent variables & Code 0* & Code $1^{*}$ \\
\hline 1 & Region & Sertão [25] & Cariri or Agreste [12] \\
\hline 2 & Farm size & $\leq 64$ ha $[21]$ & $>64$ ha $[16]$ \\
\hline 3 & Herd size & $\leq 45$ cattle $[19]$ & $>45$ cattle $[18]$ \\
\hline 4 & No. of cows on the farm & $\leq 15[24]$ & $>15[13]$ \\
\hline 5 & Predominant cattle breed & Crossbred or Zebu [31] & European [6] \\
\hline 6 & Exploitation type & Mixed or beef [8] & Dairy [29] \\
\hline 7 & Predominant type of pasture & Native [19] & Cultivate [18] \\
\hline 8 & Artificial irrigation of pastures & No $[25]$ & Yes [12] \\
\hline 9 & Recent observation of ticks on cattle ${ }^{\#}$ & No [6] & Yes [31] \\
\hline 10 & Ticks on cattle throughout the year & No [23] & Yes [14] \\
\hline 11 & Tick control with chemical acaricides on cattle & No [7] & Yes [30] \\
\hline 12 & Acaricide method of application & Others [11] & Spraying [26] \\
\hline 13 & No. of acaricide sprayings per year & $<4[12]$ & $\geq 4[25]$ \\
\hline 14 & Presence of horse flies (Tabanidae) & No [10] & Yes [27] \\
\hline 15 & Presence of mosquitoes & No [10] & Yes [27] \\
\hline 16 & Presence of horn flies & Part of the year [32] & All year long [5] \\
\hline 17 & Use of chemical control for horn flies & No [27] & Yes [10] \\
\hline 18 & Use of injectable antihelminthics & No [6] & Yes [31] \\
\hline 19 & No. of injectable antihelminthics per year & $\leq 2[26]$ & $>2[11]$ \\
\hline 20 & Use of rabies vaccination in the last 2 years & No [6] & Yes [31] \\
\hline 21 & Use of disposable needles individually & No [16] & Yes [21] \\
\hline 22 & Recent introduction of cattle into the herd & No [21] & Yes [16] \\
\hline 23 & No. of animals introduced & $\leq 2[31]$ & $>2[6]$ \\
\hline 24 & Tick infestation on introduced animals & No [26] & Yes [11] \\
\hline
\end{tabular}

*numbers between brackets refer to the number of farms with the given condition for each variable. ${ }^{*}$ all ticks found on cattle were taxonomically identified as Rhipicephalus (Boophilus) microplus during farm visits; No - Number.

Table 2. Results from immunofluorescence assay (IFA) performed with Anaplasma marginale, Babesia bigemina and Babesia bovis antigens on blood serum samples from cows in three geographic regions of the state of Paraíba, northeastern Brazil.

\begin{tabular}{ccccc}
\hline \multirow{2}{*}{ Region } & \multirow{2}{*}{ No. of cows tested } & \multicolumn{3}{c}{ No. cows serologically positive [\% (confidence level)] } \\
\cline { 3 - 5 } & & $\boldsymbol{A . ~ m a r g i n a l e}$ & $\boldsymbol{B}$. bigemina & B. bovis \\
\hline Sertáo & 342 & $56[16.4(12.6-20.7)]$ & $32[9.3(6.5-12.9)]$ & $75[21.9(17.6-26.7)]$ \\
Cariri & 115 & $25[21.7(14.6-30.4)]$ & $11[9.6(4.9-16.5)]$ & $39[33.9(25.3-43.3)]$ \\
Agreste & 52 & $3[5.8(1.2-15.9)]$ & $7[13.5(5.6-25.8)]$ & $11[21.1(11.1-34.7)]$ \\
Total & 509 & $84[16.5(13.4-20.0)]$ & $50[9.8(7.4-12.6)]$ & $125[24.5(20.9-28.5)]$ \\
\hline
\end{tabular}

No - Number

applications of injectable antihelminthics per year (no. 19) were significantly associated $(P<0.05)$ (Table 3$)$.

Through univariate analysis, the presence of at least one cow serologically positive for $B$. bigemina was statistically coupled $(P<0.20)$ with variable nos. $12,14,18$ and 23 . When these independent variables were subjected to multivariate analysis, only use of spraying for acaricide application (no. 12) and presence of horse flies on the farm (no. 14) were significantly associated $(P<0.05)$ (Table 3). Univariate analysis showed that no independent variable was associated at the $P<0.20$ significance level with prevalence of $B$. bigemina higher than $25 \%$.

By means of univariate analysis, the presence of at least one cow serologically positive for $B$. bovis was statistically coupled $(P<0.20)$ with variable nos. $6,8,9,11,12$ and 13 . When these independent variables were subjected to multivariate analysis, only recent observation of ticks on cattle (No. 9) was significantly associated $(P<0.05)$ (Table 3$)$. Univariate analysis showed that situations with more than $25 \%$ of the cows serologically positive for $B$. bovis were statistically coupled $(P<0.20)$ with variable nos. 4, 9, 11 and 13. When these independent variables were subjected to multivariate analysis, only recent observation of ticks on cattle (no. 9) was significantly associated $(P<0.05)$ (Table 3).

\section{Discussion}

Based upon the classical epidemiological conceptual model, the risk of babesiosis and anaplasmosis outbreaks can be indirectly measured by determining the proportion of cattle of a known age that have anti-Babesia spp. and anti-A. marginale antibodies (MAHONEY; ROSS, 1972; ALONSO et al., 1992; GUGLIELMONE et al., 1997). In this case, it is desirable for 
Table 3. Results from multivariate analyses between cows that were serologically positive for Anaplasma marginale, Babesia bigemina or Babesia bovis and independent variables. Each dependent variable was analyzed with independent variables that were previously selected in univariate analyses, considering $P<0.20$.

\begin{tabular}{|c|c|c|c|c|c|}
\hline Independent variables & No. of farms & $\begin{array}{c}\text { No. of farms positive } \\
(\%)\end{array}$ & Odds ratio & $\begin{array}{c}95 \% \mathrm{CI} \\
\text { (odds ratio) }\end{array}$ & $P$-value \\
\hline
\end{tabular}

Farms with $>25 \%$ of cows serologically positive for A. marginale ${ }^{* *}$

No. of acaricide sprayings on cattle per year

$\begin{array}{lll}<4 & 12 & 6(50.0)\end{array}$

$\geq 4 \quad 25 \quad 4(16.0)$

$4(16.0)$

14.3

$1.5-138.0$

0.021

No. of injectable antihelminthics per year

$\begin{array}{llllll}\leq 2 & 26 & 5(19.2) & & & \\ >2 & 11 & 5(45.5) & 10.9 & 1.1-108.7 & 0.041\end{array}$

\begin{tabular}{|c|c|c|c|c|c|}
\hline$>2$ & 11 & $5(45.5)$ & 10.9 & $1.1-108.7$ & 0.041 \\
\hline \multicolumn{6}{|c|}{ Farms with at least one cow serologically positive for B. bigemina** } \\
\hline \multicolumn{6}{|c|}{ Acaricide method of application } \\
\hline Others & 11 & $3(27.3)$ & & & \\
\hline Spraying & 26 & $16(61.5)$ & 7.5 & $1.3-42.5$ & 0.023 \\
\hline \multicolumn{6}{|c|}{ Presence of horse flies (Tabanidae) on the farm } \\
\hline No & 10 & $2(20.0)$ & & & \\
\hline Yes & 27 & $17(63.0)$ & 11.4 & $1.7-76.2$ & 0.012 \\
\hline \multicolumn{6}{|c|}{ Farms with at least one cow serologically positive for B. bovis** } \\
\hline \multicolumn{6}{|c|}{ Recent observation of ticks on cattle } \\
\hline No & 6 & $2(33.3)$ & & & \\
\hline Yes & 31 & $28(90.3)$ & 18.7 & $2.3-148.4$ & 0.006 \\
\hline \multicolumn{6}{|c|}{ Farms with $>25 \%$ of cows serologically positive for B. bovis ** } \\
\hline \multicolumn{6}{|c|}{ Recent observation of ticks on cattle } \\
\hline No & 6 & $0(0.0)$ & & & \\
\hline Yes & 31 & $17(54.8)$ & * & $*$ & 0.022 \\
\hline
\end{tabular}

*It was not possible to calculate the odds ratio because one of the values was zero. ${ }^{* *}$ dependent variable; $\mathrm{N}^{\circ}$ - number; CI - confidence interval.

primary exposure to infected vectors to occur among calves up to 7-9 months of age, when they are naturally resistant to clinical effects and develop immunity lasting for at least two years. Cattle herds under this condition are considered to present enzootic stability with regard to babesiosis or anaplasmosis (MAHONEY; ROSS, 1972). On the other hand, on farms where primary exposure to infected vectors does not occur among calves under 9 months of age, cattle herds are considered to present enzootic instability with regard to babesiosis or anaplasmosis because older seronegative cattle become highly susceptible to the clinical effects of babesiosis or anaplasmosis, and consequently, the farm is at risk of outbreaks of these diseases (MAHONEY; ROSS, 1972).

Overall, our results indicate that the farms sampled in the present study may be in a situation of enzootic instability for A. marginale, B. bigemina or $B$. bovis, since most of the animals were seronegative for at least one agent. This condition is corroborated by recent outbreaks of anaplasmosis and babesiosis reported in 24 farms in the Sertão region of Paraíba (COSTA et al., 2011). These outbreaks, which occurred from 2007 to 2009, were associated with atypically higher rainfall that favored higher vector abundance and, consequently, higher exposure of susceptible animals to infected vectors: both ticks (in the case of Babesia spp. and $A$. marginale) and biting flies (in the case of $A$. marginale) (COSTA et al., 2011).

The cattle seroprevalence values were two to three times higher for B. bovis than for B. bigemina, although both agents were generally found in low percentages in the study region, with most of the cows being seronegative. Mahoney and Ross (1972) reported that if tick populations are suppressed either by natural or by artificial conditions, cattle might not be exposed to Babesia-infected ticks because their numbers under natural conditions are extremely low. This should explain the overall low seroprevalence values found in the present study, in which only 14 farms $(37.8 \%)$ reported tick infestations throughout the year (Table 1). In addition, since primary $B$. bovis infection tends to last for a much longer period than primary $B$. bigemina infection (MAHONEY; ROSS, 1972), higher seroprevalence for B. bovis should be expected in marginal areas like the semiarid region of Paraíba, where cattle exposure to Babesia spp-infected ticks might not be frequent. Therefore, animals with primary infection due to $B$. bigemina may become seronegative before being reinfested by $B$. bigemina-infected ticks.

Three outbreaks of cattle trypanosomiasis due to $T$. vivax were recently reported on different farms in the Sertão region of Paraíba between 2002 and 2006 (BATISTA et al., 2007, 2008). While the origin of the first outbreak in 2002 remains unknown, the subsequent two outbreaks (2005 and 2006) were associated with cattle movements among these farms (BATISTA et al., 2008). These outbreaks occurred in the north of the state of Paraíba, approximately $70 \mathrm{~km}$ from the nearest farms sampled in the present study, which were located in the municipalities of Sousa and São José do Espinharas. We did not find any serological evidence of 
T. vivax infection in the cattle of the present study, which led us to conclude that this parasite is not widespread in the state. It might have encountered ecological barriers against spreading, such as absence of vectors during the typically long drought period.

Higher farm seroprevalence values (>25\%) for $A$. marginale were significantly associated with less frequent $(<4)$ acaricide spraying per year. This may have been related not only to higher cattle exposure to ticks, but also to higher exposure to biting flies, since most commercial acaricides are synthetic pyrethroids, which are potent fly repellents (MENCKE, 2006). Bloodsucking flies may play an important role in mechanical transmission of $A$. marginale in the region. Besides the fact that experimental transmission of A. marginale by tabanids has been successfully demonstrated, it has also been observed that horse flies may remain mechanically infective for at least two hours after a blood meal on an infected animal (HAWKINS et al., 1982). Indeed, some authors have considered that mechanical transmission of $A$. marginale by biting flies is even more important than biological transmission by ticks under certain conditions, especially because of the lack of transovarial transmission of $A$. marginale in $R$. (B.) microplus ticks (UILENBERG, 1970; RIBEIRO; LIMA, 1996), as well as the inability of some strains of $A$. marginale to infect ticks, including $R$. (B.) microplus (GONÇALVES RUIZ et al., 2005). Higher seroprevalences of $A$. marginale have also been associated with several $(>2)$ applications of injectable antihelminthics per year. This observation might be related to iatrogenic transmission of $A$. marginale, which has been reported to be an important transmission route for this agent among cattle in Brazil (KESSLER, 2001).

The presence of at least one cow serologically positive for $B$. bigemina on the farm was significantly associated with use of spraying for acaricide application. While this association may seem unexpected at first glance, it might be inferred that farms treating their cattle should have higher tick infestations. In Brazil, the vast majority of farmers use manual backpack sprayers for applying acaricides on cattle, which usually results in incorrect application under field conditions, and consequently, inefficient tick control (AMARAL et al., 2011). In the present study, all the farmers who reported that they sprayed their cattle also reported that they used backpack sprayers (data not shown). Therefore, inefficient application and poor tick control does not suppress the chances of cattle being exposed to B. bigemina-infected ticks. The presence of $B$. bigemina-infected cows was also associated with the presence of horse flies on the farm. Since Boophilus ticks are the only known vectors in Brazil of B. bigemina (GUGLIELMONE, 1995), it could be inferred that the noticeable presence of tabanids on the farms may have been related to suitable environmental conditions not just for horse flies but also for ticks, since humid lowlands that would provide breeding sites for tabanids may also favor pastures with suitable vegetation coverage for tick reproduction. Finally, both occurrence and higher seroprevalence of $B$. bovis on the farms were significantly associated with recent observation of ticks on cattle, which was an expected association because Boophilus ticks are the only known vectors in Brazil of B. bovis (GUGLIELMONE, 1995)

In conclusion, the present study shows that in a region of the state of Paraíba where a semiarid and hot climate prevails, bovine babesiosis and anaplasmosis occur under conditions of enzootic instability ( $\leq 75 \%$ seroprevalence). Although the sampling for our survey, which covered 37 cattle farms that were randomly selected according to logistic reasons, does not statistically represent the whole diversity of situations in the state, the results obtained from these 37 farms were very consistent regarding the serological results; i.e., with a few exceptions, most animals on the farms were seronegative for $B$. bigemina, $B$. bovis and $A$. marginale. The characteristic weather (long drought period) and vegetation type (Caatinga) of the region seem to be related to this enzootic instability, similarly to the conditions reported for the semiarid Chaco biome in northern Argentina (GUGLIELMONE et al., 1997). Thus, adoption of yearly vaccination of calves may be an appropriate practice for preventing babesiosis or anaplasmosis outbreaks on farms within the Caatinga biome of the state of Paraíba, just like it has been adopted in southern Brazil, where enzootic instability also prevails, but due to another reason: the extremely low autumnwinter temperatures.

\section{Acknowledgements}

We thank Alberto L. Rodrigues for his technical support during field work. This work was supported by the Fundação de Amparo a Pesquisa do Estado de Sáo Paulo (FAPESP) and Conselho Nacional de Desenvolvimento Científico e Tecnológico (CNPq).

\section{References}

Alonso M, Arellano-Sota C, Cereser VH, Cordoves CO, Guglielmone AA, Kessler R, et al. Epidemiology of bovine anaplasmosis and babesiosis in Latin America and the Caribbean. Rev Sci Tech Off Int Epiz 1992; 11(3): 713-733.

Amaral MAZ, Rocha CMBM, Faccini JL, Furlong J, Monteiro CMO, Prata MCA. Perceptions and attitudes among milk producers in Minas Gerais regarding cattle tick biology and control. Rev Bras Parasitol Vet 2011; 20(3): 194-201. PMid:21961747. http://dx.doi.org/10.1590/ S1984-29612011000300003

Andrade-Lima D. The Caatinga dominium. Rev Bras Bot 1981; 4: 149-153.

Aragão H. Ixodidas brasileiros e de alguns paizes limitrophes. Mem Inst Oswaldo Cruz 1936; 31(4): 759-843. http://dx.doi.org/10.1590/S007402761936000400004

Bastos CV, Passos LM, Facury-Filho EJ, Rabelo EM, De la Fuente J, Ribeiro MF. Protection in the absence of exclusion between two Brazilian isolates of Anaplasma marginale in experimentally infected calves. Vet J2010; 186(3): 374-378. PMid:19837622. http://dx.doi.org/10.1016/j. tvjl.2009.09.013

Batista JS, Riet-Correa F, Teixeira MMG, Madruga CR, Simões SDV, Maia TF. Trypanosomiasis by Trypanosoma vivax in cattle in the Brazilian semiarid: description of an outbreak and lesions in the nervous system. Vet Parasitol 2007; 143(2): 174-181. PMid:16965857. http://dx.doi. org/10.1016/j.vetpar.2006.08.017

Batista JS, Bezerra FSB, Lira RA, Carvalho JRG, Rosado Neto AM, Petri AA, et al. Clinical, epidemiological and pathological signs of natural infection in cattle by Trypanosoma vivax in Paraíba, Brazil. Pesq Vet Bras 2008; 28(1): 63-69. http://dx.doi.org/10.1590/S0100736X2008000100010 
Cabrera AL, Willink A. Biogeografía de América Latina. Washington: Organización de los Estados Americanos; 1973.

Campos Pereira M, Labruna MB, Szabo MPJ, Klafke GM. Rhipicephalus (Boophilus) microplus - Biologia, Controle e Resistência. São Paulo: MedVet Livros; 2008.

Costa VMM, Rodrigues AL, Medeiros JMA, Labruna MB, Simóes SVD, Riet-Correa F. Tristeza parasitária bovina no Sertão da Paraíba. Pesq Vet Bras 2011; 31(3): 239-243. http://dx.doi.org/10.1590/S0100736X2011000300009

Costa-Júnior LM, Rabelo EM, Martins Filho OA, Ribeiro MF. Comparison of different direct diagnostic methods to identify Babesia bovis and Babesia bigemina in animals vaccinated with live attenuated parasites. Vet Parasitol 2006; 139(1-3): 231-236. PMid:16580136. http:// dx.doi.org/10.1016/j.vetpar.2006.02.034

Cuglovici DA, Bartholomeu DC, Reis-Cunha JL, Carvalho AU, Ribeiro MF. Epidemiologic aspects of an outbreak of Trypanosoma vivax in a dairy cattle herd in Minas Gerais state, Brazil. Vet Parasitol 2010; 169(3-4): 320-326. PMid:20138431. http://dx.doi. org/10.1016/j.vetpar.2009.12.041

Gonçalves Ruiz PM, Passos LM, Ribeiro MF. Lack of infectivity of a Brazilian Anaplasma marginale isolate for Boophilus microplus ticks. Vet Parasitol 2005; 128(3-4): 325-331. PMid:15740870. http://dx.doi. org/10.1016/j.vetpar.2004.11.017

Guglielmone AA. Epidemiology of babesiosis and anaplasmosis in South and Central America. Vet Parasitol 1995; 57(1-3): 109-119. http://dx.doi. org/10.1016/0304-4017(94)03115-D

Guglielmone AA, Echaide ST, Pérez y Santaella M, Iglesias JA, Vanzini VR, Lugaresi CI, et al. Cross-sectional estimation of Babesia bovis antibody prevalence in an area of Argentina used for extensive cattle breeding as an aid to control babesiosis. Prev Vet Med 1997; 30(2): 151-154. http:// dx.doi.org/10.1016/S0167-5877(96)01099-9

Hawkins JA, Love JN, Hidalgo RJ. Mechanical transmission of anaplasmosis by tabanids (Diptera: Tabanidae). Am J Vet Res 1982; 43(4): 732-734. PMid:7073099.

Hoare CA. The trypanosomes of mammals: a zoological monograph. Oxford: Blackwell; 1972.

Instituto Interamericano de Cooperação para a Agricultura - IICA. Técnicas para el diagnostico de babesiosis y anaplasmosis bovina. San José: IICA; 1987.

Kessler RH. Consideraçôes sobre a transmissão de Anaplasma marginale. Pesq Vet Bras 2001; 21(4): 177-179. http://dx.doi.org/10.1590/S0100736X2001000400009

Madruga CR, Aycardi E, Kessler RH, Schenk MAM, Figueiredo GR, Curvo JBE. Níveis de anticorpos anti-Babesia bigemina e Babesia bovis, em bezerros em bezerros da raça Nelore, Ibagé e cruzamentos de Nelore. Pesq Agropec Bras 1984; 19(9): 1163-1168.

Madruga CR, Kessler RH, Gomes A, Schenk MAM, Andrade DF. Níveis de anticorpos e parasitemia de Anaplasma marginale em área enzoótica, nos bezerros da raça Nelore, Ibagé e cruzamentos de Nelore. Pesq Agropec Bras 1985; 20(1): 135-142.

Mahoney DF, Ross DR. Epizootiological factors in the control of bovine babesiosis. Aust Vet J 1972; 48(5): 292-298. PMid:4672119. http:// dx.doi.org/10.1111/j.1751-0813.1972.tb05160.x

Marana ERM, Dias JA, Freire RL, Vicentini JC, Vidotto MC, Vidotto O. Soroprevalência de Anaplasma marginale em bovinos da região Centro-Sul do estado do Paraná, Brasil, por um teste imunoenzimático competitivo utilizando proteína recombinante MSP5-PR1. Rev Bras Parasitol Vet 2009; 18(1): 20-26. PMid:19500456. http://dx.doi. org/10.4322/rbpv.01801004

Martins JR, Correa BL, Ceresér VH, Arteche CCP, Guglielmone AA. Some aspects of the epidemiology of Babesia bovis in Santana do Livramento, southern Brazil. Rev Bras Parasitol Vet 1994; 3(2): 75-78.

Mencke N. Acaricidal and repellent properties of permethrin, its role in reducing transmission of vector-borne pathogens. Parassitologia 2006; 48(1-2): 139-140. PMid:16881417.

Nari A, Solari MA. Epidemiología y control del Boophilus microplus en Uruguay. Su relación con Babesia spp. Rvta Cub Cienc Vet 1991; 22(3): 149-160.

Patarroyo JHS, Ribeiro MFB, Santos JL, Faria JE. Epidemiologia das babesioses bovinas no Estado de Minas Gerais. I. Prevalência de anticorpos fluorescentes na Zona da Mata, MG. Arq Bras Med Vet Zoot 1987; 39(3): 423-429.

Ribeiro MFB, Reis R. Prevalência da anaplasmose em quatro regiōes do Estado de Minas Gerais. Arq Esc Vet UFMG 1981; 33(1): 57-62.

Ribeiro MF, Lima JD. Morphology and development of Anaplasma marginale in midgut of engorged female ticks of Boophilus microplus. Vet Parasitol 1996; 61(1-2): 31-39. http://dx.doi.org/10.1016/03044017(95)00800-4

Santos HQ, Linhares GFC, Madruga CR. Estudo da prevalência de anticorpos anti-Babesia bovis e anti-Babesia bigemina em bovinos de leite da microrregião de Goiânia determinada pelos testes de imunofluorescência indireta e Elisa. Cien Anim Bras 2001; 2(2): 133-137.

Statistical Package for the Social Sciences - SPSS. SPSS for Windows. SPSS Base 9.0.1. Users guide. Chicago: SPSS Inc.; 1999.

Uilenberg G. Notes sur les babésioses et l'anaplasmose des bovins à Madagascar. IV. Note additionnelle sur la transmission. Rev Elev Méd Vét Pays Trop 1970; 23(3): 309-312. PMid:5504545. 